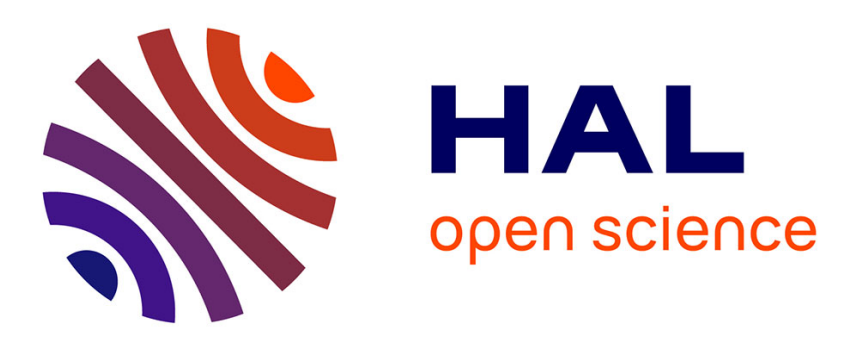

\title{
A New Synthetic Method and Solution Equilibria for the Chlorotitanate(IV) Anions- Evidence for the Existence of a New Species: [Ti2Cl11]3-
}

Emmanuel Robé, Jean-Claude Daran, Sandrine Vincendeau, Rinaldo Poli

\section{- To cite this version:}

Emmanuel Robé, Jean-Claude Daran, Sandrine Vincendeau, Rinaldo Poli. A New Synthetic Method and Solution Equilibria for the Chlorotitanate(IV) Anions- Evidence for the Existence of a New Species: [Ti2Cl11]3-. European Journal of Inorganic Chemistry, 2004, 2004 (20), pp.4108-4114. 10.1002/ejic.200400293 . hal-03278488

\section{HAL Id: hal-03278488 \\ https://hal.science/hal-03278488}

Submitted on 7 Jul 2021

HAL is a multi-disciplinary open access archive for the deposit and dissemination of scientific research documents, whether they are published or not. The documents may come from teaching and research institutions in France or abroad, or from public or private research centers.
L'archive ouverte pluridisciplinaire HAL, est destinée au dépôt et à la diffusion de documents scientifiques de niveau recherche, publiés ou non, émanant des établissements d'enseignement et de recherche français ou étrangers, des laboratoires publics ou privés. 
A new synthetic method and solution equilibria for the chlorotitanate(IV) anions. Evidence for the existence of a new species: $\left[\mathrm{Ti}_{2} \mathrm{Cl}_{11}\right]^{3-}$

Emmanuel Robé, ${ }^{\mathrm{a}}$ Jean-Claude Daran, ${ }^{\mathrm{b}}$ Sandrine Vincendeau ${ }^{\mathrm{b}}$ and Rinaldo Poli*a,b

a'Laboratoire de Synthèse et d'Electrosynthèse Organométalliques (LSEO UMR 5632),

Université de Bourgogne, Faculté de Sciences "Gabriel”, 6 boulevard Gabriel, 21000

Dijon, France.

${ }^{\mathrm{b}}$ Laboratoire de Chimie de Coordination (LCC UPR 8241), 205 Route de Narbonne, 31077 Toulouse Cedex, France.

Proofs to:

R. Poli

$+33-561333173$

$+33-561553003$

poli@1cc-toulouse.fr 


\begin{abstract}
$\mathrm{TiCl}_{3}$ is oxidized by $\mathrm{SOCl}_{2}$ in the presence of the appropriate amount of $\left[\mathrm{NEt}_{3} \mathrm{Bz}\right] \mathrm{Cl}$ or $[\mathrm{PPN}] \mathrm{Cl}[\mathrm{Bz}=$ benzyl; $\mathrm{PPN}=$ bis(triphenylphoshine)iminium $]$ to afford the corresponding salts of $\left[\mathrm{Ti}_{2} \mathrm{Cl}_{9}\right]^{-},\left[\mathrm{Ti}_{2} \mathrm{Cl}_{10}\right]^{2-}$ or $\left[\mathrm{TiCl}_{6}\right]^{2-}$. The results of cyclic voltammetric and solution IR studies in the $\mathrm{M}-\mathrm{Cl}$ stretching region are interpreted in terms of a rapid chloride redistribution equilibrium between $\left[\mathrm{Ti}_{2} \mathrm{Cl}_{10}\right]^{2-}$ on one side and a mixture of $\left[\mathrm{Ti}_{2} \mathrm{Cl}_{9}\right]^{-}$and a previously unreported $\left[\mathrm{Ti}_{2} \mathrm{Cl}_{11}\right]^{3-}$ on the other side. In the solid state, however, a compound with the $[\mathrm{PPN}]_{3}\left[\mathrm{Ti}_{2} \mathrm{Cl}_{11}\right]$ stoichiometry exists as a mixture of $[\mathrm{PPN}]_{2}\left[\mathrm{Ti}_{2} \mathrm{Cl}_{10}\right]$ and $[\mathrm{PPN}]_{2}\left[\mathrm{TiCl}_{6}\right]$. The PPN salt of $\left[\mathrm{Ti}_{2} \mathrm{Cl}_{9}\right]^{-}$has been structurally characterized by X-ray diffractometry.
\end{abstract}

Keywords: titanium, thionyl chloride, electrochemistry, low-frequency infrared spectroscopy, undecachloroditatanate(IV) 


\section{Introduction}

Homoleptic chlorometallates are a wide class of fundamentally important coordination compounds. They are in general easily accessible upon addition of the required amount of halide ions to the neutral metal halide. For Ti(IV), four different anionic complexes are known, the ennachlorodititanate, $\left[\mathrm{Ti}_{2} \mathrm{Cl}_{9}\right]^{-}$, the decachlorodititanate, $\left[\mathrm{Ti}_{2} \mathrm{Cl}_{10}\right]^{2-}$, the pentachlorotitanate, $\left[\mathrm{TiCl}_{5}\right]^{-}$, and the hexachlorotitanate, $\left[\mathrm{TiCl}_{6}\right]^{2-}$, formally related to $\mathrm{TiCl}_{4}$ by the addition of one half, one, or two $\mathrm{Cl}^{-}$ions per titanium, respectively, see Scheme 1. $^{[1]}$ The choice between mononuclear or dinuclear pentachlorotitanate seems to be controlled by the size of the counterion. ${ }^{[2]}$ Since $\mathrm{TiCl}_{3}$ is used extensively as a precursor of Ziegler-Natta polymerization catalysts, ${ }^{[3-8]}$ its coordination chemistry has been widely explored. However, the only reported chlorotitanate(III) anions are apparently the edge-sharing bioctahedral $\left[\mathrm{Ti}_{2} \mathrm{Cl}_{9}\right]^{3-}$ and the mononuclear octahedral $\left[\mathrm{TiCl}_{6}\right]^{3-} \cdot{ }^{[9-11]}$ Furthermore, these ions are prepared at high temperatures in the solid state (no solvent) ${ }^{[12,13]}$ while little information is available on their properties in solution.

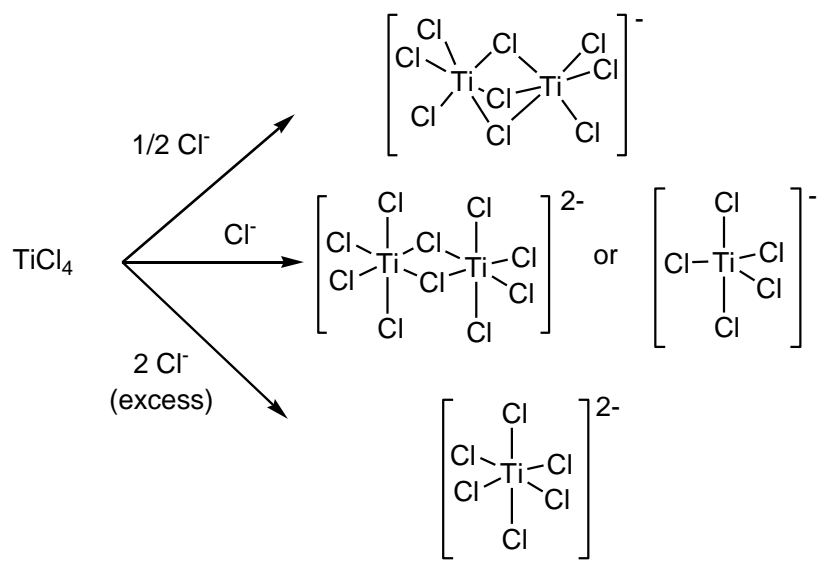




\section{Scheme 1}

In an attempt to gain access to soluble versions of these anionic complexes and perhaps to prepare the yet unknown ${ }^{[14]}$ decachlorodititanate(III) tetraanion, $\left[\mathrm{Ti}_{2} \mathrm{Cl}_{10}\right]^{4-}$, we have investigated the interaction between $\mathrm{TiCl}_{3}$ and chloride salts in solution. Given the hydrolytic sensitivity of $\mathrm{Ti}(\mathrm{III})$, our approach has consisted in the use of $\mathrm{SOCl}_{2}$ as solvent, since this is a well known medium for insuring anhydrous conditions for

transition metal chlorides. ${ }^{[15]}$ The result of this interaction, surprising yielding metal oxidation, are reported here. Furthermore, we present new information on the solution behavior of the $\left[\mathrm{Ti}_{2} \mathrm{Cl}_{10}\right]^{2-}$ ion and spectroscopic and electrochemical evidence for the existence in solution of a previously unreported $\left[\mathrm{Ti}_{2} \mathrm{Cl}_{11}\right]^{3-}$ ion.

\section{Experimental}

General Procedures. All manipulations were carried out under an atmosphere of dry and oxygen-free argon with standard Schlenk techniques. $\mathrm{CH}_{2} \mathrm{Cl}_{2}$ was purified by reflux and distillation over $\mathrm{P}_{4} \mathrm{O}_{10}$ under argon. Pentane was purified by reflux over sodium benzophenone ketyl and distilled under argon. Cyclic voltammograms were recorded with an EG\&G 362 potentiostat connected to a Macintosh computer through MacLab hardware/sofware. The electrochemical cell was fitted with an Ag-AgCl reference electrode, a platinum disk working electrode and a platinum wire counterelectrode. $\left[\mathrm{Bu}_{4} \mathrm{~N}\right] \mathrm{PF}_{6}$ (ca. $0.1 \mathrm{M}$ ) was used as supporting electrolyte in $\mathrm{CH}_{2} \mathrm{Cl}_{2}$. All potentials are reported relative to the ferrocene standard, which was added to each solution and measured at the end of the experiments. The infrared spectra were recorded 
on a Brucker Vector 22 instrument equipped with a Globar (MIR) source. The solution spectra in the far IR (480-300 $\mathrm{cm}^{-1}$ ) region were obtained from $\mathrm{CH}_{2} \mathrm{Cl}_{2}$ solutions in polyethylene cells $(0.5 \mathrm{~mm}$ path length). The elemental analyses were carried out by the analytical services of LSEO and LCC with Fisons EA 1108 and Perkin Elmer 2400 instruments, respectively. Titanium(III) chloride (Aldrich), triethylbenzylammonium chloride (Aldrich) and bis(triphenylphosphine)iminium (PPN) chloride (Aldrich) were used as received.

Synthesis of $\left[\mathbf{N E t} \mathbf{H}_{3} \mathbf{B z}\right]_{2}\left[\mathbf{T i}_{2} \mathrm{Cl}_{10}\right]$. A Schlenk tube was charged with $\mathrm{TiCl}_{3}(0.114 \mathrm{~g}$, $0.74 \mathrm{mmol})$ and $\left[\mathrm{NEt}_{3} \mathrm{Bz}\right] \mathrm{Cl}(0.174 \mathrm{~g}, 0.76 \mathrm{mmol})$. Thionyl chloride $(20 \mathrm{~mL})$ was added by syringe under magnetic stirring. Warning: the reaction between $\mathrm{SOCl}_{2}$ and water produces toxic $\mathrm{SO}_{2}$ and $\mathrm{HCl}$, therefore the reaction must be carried out under a well ventilated fume hood. The gaseous products were eliminated through an oil bubbler. The dark-purple suspension transformed gradually into a yellow solution. After four hours of stirring at room temperature, pentane $(50 \mathrm{~mL})$ was added, causing the precipitation of the product as a yellow powder. After filtration, the solid was washed with pentane and dried under vacuum for three hours. Yield $276 \mathrm{~g} \mathrm{(45 \% ).} \mathrm{Anal.} \mathrm{Calcd.}$ for $\mathrm{C}_{26} \mathrm{H}_{44} \mathrm{Cl}_{10} \mathrm{~N}_{2} \mathrm{Ti}_{2}:$ C, 37.4; H, 5.3; N, 3.4. Found: C, 37.8; H, 5.1; N, 3.3.

Synthesis of $[\mathbf{P P N}]_{2}\left[\mathbf{T i}_{2} \mathrm{Cl}_{10}\right]$. Following an identical procedure as described above for $\left[\mathrm{NEt}_{3} \mathrm{Bz}\right]_{2}\left[\mathrm{Ti}_{2} \mathrm{Cl}_{10}\right], 0.834 \mathrm{~g}(88 \%)$ of $[\mathrm{PPN}]_{2}\left[\mathrm{Ti}_{2} \mathrm{Cl}_{10}\right]$ were obtained starting from $\mathrm{TiCl}_{3}(0.192 \mathrm{~g}, 1.24 \mathrm{mmol})$ and PPNCl $(0.715 \mathrm{~g}, 1.25 \mathrm{mmol})$. Anal. Calcd. for $\mathrm{C}_{72} \mathrm{H}_{60} \mathrm{Cl}_{10} \mathrm{~N}_{2} \mathrm{P}_{4} \mathrm{Ti}_{2}:$ C, 56.6; H, 4.0; N, 1.8. Found: C, 56.0; H, 3.7; N, 1.8.

Synthesis of [PPN][Ti2 Cl9]. A Schlenk tube was charged with $\mathrm{TiCl}_{3}(0.565 \mathrm{~g}, 3.67$ mmol) and PPNCl (1.050 g, $1.83 \mathrm{mmol})$. Thionyl chloride $(30 \mathrm{~mL})$ was added by syringe 
under magnetic stirring. Warning: the reaction between $\mathrm{SOCl}_{2}$ and water produces toxic $\mathrm{SO}_{2}$ and $\mathrm{HCl}$, therefore the reaction must be carried out under a well ventilated fume hood. The suspension was refluxed for one hour. The gaseous products were eliminated through an oil bubbler. The dark-purple suspension transformed gradually into a yellow solution. After cooling to room temperature, it was concentrated until approximately 10 $\mathrm{mL}$ and pentane $(60 \mathrm{~mL})$ was added, causing the precipitation of the product as a yellow powder. After filtration, the solid was washed with pentane and dried under vacuum. Yield 1.574 g (87 \%). Anal. Calcd. for $\mathrm{C}_{36} \mathrm{H}_{30} \mathrm{Cl}_{9} \mathrm{NP}_{2} \mathrm{Ti}_{2}$ : C, 45.3; H, 3.2. Found: C, 44.3; H, 2.8.

Synthesis of $[\mathbf{P P N}]_{2}\left[\mathrm{TiCl}_{6}\right]$. Following an identical procedure as described above for $[\mathrm{PPN}]\left[\mathrm{Ti}_{2} \mathrm{Cl}_{9}\right], 0.822 \mathrm{~g}(96 \%)$ of $\left[\mathrm{PPN}_{2}\left[\mathrm{TiCl}_{6}\right]\right.$ were obtained starting from $\mathrm{TiCl}_{3}$ $(0.099 \mathrm{~g}, \quad 0.64 \mathrm{mmol})$ and PPNCl $(0.740 \mathrm{~g}, 1.29 \mathrm{mmol})$. Anal. Calcd. for $\mathrm{C}_{72} \mathrm{H}_{60} \mathrm{Cl}_{10} \mathrm{~N}_{2} \mathrm{P}_{4} \mathrm{Ti}_{2}$ : C, 64.6; H, 4.5; N, 2.1. Found: C, 63.8; H, 4.1; N, 2.0. The solid state and solution IR characterization is presented in the Results and Discussion section.

Synthesis of a product with stoichiometry $[\mathrm{PPN}]_{3}\left[\mathrm{Ti}_{2} \mathrm{Cl}_{11}\right]$. Following an identical procedure as described above for $[\mathrm{PPN}]\left[\mathrm{Ti}_{2} \mathrm{Cl}_{9}\right], \mathrm{TiCl}_{3}(0.112 \mathrm{~g}, 0.73 \mathrm{mmol})$ and PPNCl $(0.628 \mathrm{~g}, 1.09 \mathrm{mmol})$ yielded $1.534 \mathrm{~g}(46 \%)$ of a solid product corresponding to the $[\mathrm{PPN}]_{3}\left[\mathrm{Ti}_{2} \mathrm{Cl}_{11}\right]$ stoichiometry. Anal. Calcd. for $\mathrm{C}_{72} \mathrm{H}_{60} \mathrm{Cl}_{10} \mathrm{~N}_{2} \mathrm{P}_{4} \mathrm{Ti}_{2}: \mathrm{C}, 61.7 ; \mathrm{H}, 4.3$; N, 2.0. Found: C, 60.6; H, 3.8; N, 1.9. The solid state and solution IR characterization is presented in the Results and Discussion section.

X-ray Structural Determinations for Compound [PPN][Ti2 Cl9]. A single crystal was mounted under inert perfluoropolyether at the tip of a glass fiber and cooled in the cryostream of the Oxford-Diffraction XCALIBUR CCD diffractometer. Data were 
collected using the monochromatic MoK $\alpha$ radiation $(\lambda=0.71073)$. The structures was solved by direct methods (SIR97) ${ }^{[16]}$ and refined by least-squares procedures on $F^{2}$ using SHELXL-97. ${ }^{[17]}$ All $\mathrm{H}$ atoms attached to carbon were introduced in calculation in idealised positions $[\mathrm{d}(\mathrm{CH})=0.96 \AA$ 品 $]$ and treated as riding models. The drawing of the molecules (Figure 1) was realised with the help of ORTEP32. ${ }^{[18]}$ Crystal data and refinement parameters are shown in Table 1 and selected bond distances and angles are listed in Table 2.

Crystallographic data (excluding structure factors) have been deposited with the Cambridge Crystallographic Data Centre as supplementary publication no. CCDC 233004. Copies of the data can be obtained free of charge on application to the Director, CCDC, 12 Union Road, Cambridge CB2 1EZ, UK (fax: (+44) 1223-336-033; e-mail: deposit@ccdc.cam.ac.uk).

<Table 1, Table 2>

\section{Results and Discussion}

\section{(a) Syntheses}

The addition of one equivalent of chloride, either as the triethylbenzylammonium $\left(\mathrm{Et}_{3} \mathrm{BzN}\right)$ or the bis(triphenylphosphine)iminium (PPN) salt, to $\mathrm{TiCl}_{3}$ in $\mathrm{SOCl}_{2}$ results in a smooth reaction at room temperature accompanied by a sharp color change from dark purple to yellow. The color is indicative of chloro complexes of $\mathrm{Ti}(\mathrm{IV})$. Indeed, the selective product of the reactions are the decachlorodititanate(IV) salts, see Equation 1. 
The products are obtained in a pure state and in good yields. They are moderately soluble in dichloromethane, the PPN salt being more soluble than the ammonium salt. The dinuclear nature of these salts is demonstrated by their IR properties (vide infra).

\section{Equation 1}

$2 \mathrm{TiCl}_{3}+2[\mathrm{Cat}] \mathrm{Cl}+2\{\mathrm{Cl}\} \stackrel{\mathrm{SOCl}_{2}}{\longrightarrow}[\mathrm{Cat}]_{2}\left[\mathrm{Ti}_{2} \mathrm{Cl}_{10}\right] \quad\left(\mathrm{Cat}=\mathrm{NEt}_{3} \mathrm{Bz}, \mathrm{PPN}\right)$

By changing the stoichiometry to one or four equivalents of chloride salt per two of $\mathrm{TiCl}_{3}$, the ennachlorodititanate(IV), $\left[\mathrm{Ti}_{2} \mathrm{Cl}_{9}\right]^{-}$, and the hexachlorotitanate(IV), $\left[\mathrm{TiCl}_{6}\right]^{2-}$, are obtained in good yields, see Equation 2 and Equation 3. We have also obtained a product having the stoichiometry $[\mathrm{PPN}]_{3}\left[\mathrm{Ti}_{2} \mathrm{Cl}_{11}\right]$ by using a $3: 2 \mathrm{PPNCl} / \mathrm{TiCl}_{3}$ ratio. The solid state and solution nature of these products will be discussed in the next section. The necessary chlorine atoms for the stoichiometries of Equation 1, Equation 2 and Equation 3 are undoubtedly provided by the thionyl chloride solvent, which must therefore be reduced. The oxidizing properties of thionyl chloride relative to low-valent metal halides do not appear to be extensively explored. A metal oxidation process has been witnessed for the dehydration of $\mathrm{SnCl}_{2} \cdot 2 \mathrm{H}_{2} \mathrm{O}$ (leading to $\mathrm{SnCl}_{4}$ while elemental sulfur was found amongst the reduction products), whereas the dehydration of $\mathrm{TlCl}_{3} \cdot \mathrm{xH}_{2} \mathrm{O}$, which is affected by a spontaneous reduction to $\mathrm{Tl}(\mathrm{I})$ chloride when the salt is thermally dehydrated, leads to pure $\mathrm{TlCl}_{3}$ when using $\mathrm{SOCl}_{2} \cdot{ }^{[15]}$ Another potentially reducing metal chloride is $\mathrm{CrCl}_{2}$ but the dehydration of the corresponding hydrate with $\mathrm{SOCl}_{2}$ has apparently never been described ${ }^{[19]}$ (whereas it is described with $\mathrm{COCl}_{2}$ ). ${ }^{[15]}$ Unlike the above mentioned dehydration of $\mathrm{SnCl}_{2}$, we have not witnessed the formation of any 
elemental sulfur. It is known that $\mathrm{SOCl}_{2}$ decomposes at high temperatures to yield $\mathrm{Cl}_{2}$, $\mathrm{SO}_{2}$ and $\mathrm{S}_{2} \mathrm{Cl}_{2},{ }^{[20,}{ }^{21]}$ but, remarkably, the $\mathrm{Ti}$ oxidation process that we report here smoothly occurs at room temperature. We have not further explored the nature of the reduced sulfur products in this reaction.

\section{Equation 2}

$2 \mathrm{TiCl}_{3}+[\mathrm{PPN}] \mathrm{Cl}+2\{\mathrm{Cl}\} \stackrel{\mathrm{SOCl}_{2}}{\longrightarrow}[\mathrm{PPN}]\left[\mathrm{Ti}_{2} \mathrm{Cl}_{9}\right]$

\section{Equation 3}

$\mathrm{TiCl}_{3}+2[\mathrm{PPN}] \mathrm{Cl}+\{\mathrm{Cl}\} \stackrel{\mathrm{SOCl}_{2}}{\longrightarrow}[\mathrm{PPN}]_{2}\left[\mathrm{TiCl}_{6}\right]$

\section{(b) Electrochemical and spectroscopic characterization}

Still with the goal in mind of exploring the solution chemistry of the chlorotitanate(III) complexes, we have carried out electrochemical investigations of the chlorotitanate(IV) anions. Previous electrochemical investigations on Ti(IV) chloride systems appear to be limited to $\mathrm{TiCl}_{4}$ in $\mathrm{AlCl}_{3}$-chloride melts. ${ }^{[22,23]}$ Basic melts $(\mathrm{Cl} / \mathrm{Al}>$ 4) exhibit only a reversible reduction that has been attributed to the $\left[\mathrm{TiCl}_{6}\right]^{2-}$ ion, ${ }^{[22]}$ whereas Lewis acidic melts show less reversible features that are attributed to less chloride-rich anions whose nature depends on the melt composition. ${ }^{[23]}$ It is reasonable to expect that the reduction process to $\mathrm{Ti}(\mathrm{III})$ correlates with the effective charge at the metal center, a greater electron density leading to a more difficult reduction process. 
Therefore, one could reasonably expect a trend of reduction potentials in the order $\left[\mathrm{TiCl}_{6}\right]^{2-}<\left[\mathrm{Ti}_{2} \mathrm{Cl}_{10}\right]^{2-}<\left[\mathrm{Ti}_{2} \mathrm{Cl}_{9}\right]^{-}$.

A cyclic voltammetric analysis of $\left[\mathrm{Ti}_{2} \mathrm{Cl}_{10}\right]^{2-}$ in $\mathrm{CH}_{2} \mathrm{Cl}_{2}$ shows that the $\mathrm{Ti}(\mathrm{IV})$ center undergoes the expected reduction process, which is irreversible. This irreversibility is probably linked to loss of chloride ions upon reduction, induced by the accumulation of too much negative charge and by the possible rearrangement to a triply-bridged, facesharing bioctahedral $\left[\mathrm{Ti}_{2} \mathrm{Cl}_{9}\right]^{2-}$ species. Such mixed-valence complex is apparently not yet known. The surprising observation, however, is the complexity of the reduction wave (see Figure 1), showing at least two distinct processes, the main one having a cathodic peak potential $\mathrm{E}_{\mathrm{p}, \mathrm{c}}=-1.03 \mathrm{~V}$, with a broad shoulder between ca. -0.8 and $-0.6 \mathrm{~V}$.

\section{$<$ Figure 1>}

The possibility that the complexity of this voltammetric response could result from sample impurities was soon excluded by the reproducibility when measuring several samples obtained from different syntheses. The key to understand the reason of this complexity comes from the voltammetric measurement after the addition of excess chloride ions, which should quantitatively convert the electroactive species to the $\left[\mathrm{TiCl}_{6}\right]^{2-}$ ion (see Scheme 1), according to the literature. The single irreversible reduction wave at $E_{p, c}=-1.13 \mathrm{~V}$ that is obtained under these conditions (see Figure 1) may therefore be attributed to the reduction of this ion. Note that this wave is irreversible, whereas full reversibility is observed in a $\mathrm{AlCl}_{3} /$ chloride melt. $^{[22]}$ This observation fully agrees with the likely instability of a reduced $\left[\mathrm{TiCl}_{6}\right]^{3-}$ ion towards chloride ion loss. This 
wave occurs at a very similar potential as the main wave of the $\left[\mathrm{Ti}_{2} \mathrm{Cl}_{10}\right]^{2-}$ solution in the absence of free chloride ions. The second species is reduced at a less negative potential, therefore it must contain a higher effective positive charge on the metal center (lower $\mathrm{Cl} / \mathrm{Ti}$ ratio). A logical hypothesis is to assign this wave to the $\left[\mathrm{Ti}_{2} \mathrm{Cl}_{9}\right]^{-}$ion. Indeed, the cyclic voltammogram for a solution prepared from the isolated $\left[\mathrm{Ti}_{2} \mathrm{Cl}_{9}\right]^{-}$salt shows an irreversible wave with $\mathrm{E}_{\mathrm{p}, \mathrm{c}}=-0.76 \mathrm{~V}$, corresponding closely to the shoulder of the $\left[\mathrm{Ti}_{2} \mathrm{Cl}_{10}\right]^{2-}$ solution in the absence of free chloride ions. Therefore, we conclude that a chloride dissociation equilibrium exists in solution starting from the dianionic decachloro species, according to Equation 4. The chloride ions that are freed up in solution can then break the bridge bonds of the decachloro species to yield a more chloride-rich species. It would seem reasonable to assume that this species is the mononuclear dianion, $\left[\mathrm{TiCl}_{6}\right]^{2-}$. However, the results obtained from a parallel IR investigation tell a different story.

\section{Equation 4}

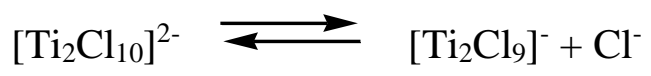

An independent investigation of the solution equilibria is complicated by the absence of available spectroscopic probes such as spin $1 / 2$ nuclei for an NMR investigation or unpaired electrons for an EPR investigation. The use of ${ }^{47} \mathrm{Ti}$ and ${ }^{49} \mathrm{Ti}$ NMR is unsatisfactory for compounds where the $\mathrm{Ti}$ center has lower than cubic symmetry. ${ }^{[23,24]}$ A suitable solution is provided by infrared spectroscopy in the low wavenumber region, which is sensitive to the $\mathrm{Ti}-\mathrm{Cl}$ stretching vibrations. Infrared studies of chlorotitanate ions have been previously published, but these have mostly been 
confined to solid samples, ${ }^{[2,25-27]}$ the reason being that the solubility of most available salts (e.g. with $\mathrm{K}^{+}, \mathrm{Rb}^{+}, \mathrm{Cs}^{+}, \mathrm{Et}_{2} \mathrm{NH}_{2}{ }^{+}$, and $\left.\mathrm{Et}_{4} \mathrm{~N}^{+}\right)^{[26]}$ is too low. The PPN salts reported here are sufficiently soluble in dichloromethane to yield reasonable intensities $(A>1$ for some bands in $0.5 \mathrm{~mm}$ pathlength polyethylene cells, see Figure 2). It can be noted that the $\mathrm{PPN}^{+}$ion does not interfere in the investigated region, since it shows only a very weak band at $464 \mathrm{~cm}^{-1}$.

$<$ Figure 2>

First, we shall comment on the dichotomy between $\left[\mathrm{Ti}_{2} \mathrm{Cl}_{10}\right]^{2-}$ and its mononuclear version, the pentachlorotitanate(IV) anion $\left[\mathrm{TiCl}_{5}\right]^{-},{ }^{[2,25,28-30]}$ and then on the species with a different $\mathrm{Cl} / \mathrm{Ti}$ ratio. Previous studies have shown that, in the solid state, the pentachlorotitanate(IV) salts feature a dichloro-bridged bioctahedral geometry for the anion in the presence of small cations, whereas salts of larger cations are mononuclear. ${ }^{[2]}$ The $\mathrm{PCl}_{4}{ }^{+}$salt was shown to undergo a temperature-dependent monomer-dimer equilibrium. $^{[25]}$ The solid state spectrum of the mononuclear salt is characterized by a very strong band at $348 \mathrm{~cm}^{-1}$, which is absent from the solution spectrum of $[\mathrm{PPN}]_{2}\left[\mathrm{Ti}_{2} \mathrm{Cl}_{10}\right]$. On the other hand, the solid state spectra of dinuclear anions are characterized by a very strong band around $380 \mathrm{~cm}^{-1}$ (385 for the $\mathrm{NEt}_{4}$ salt, 377 for the $\mathrm{PCl}_{4}$ salt). ${ }^{[2]} \mathrm{A}$ band in this region is indeed observed in the solution spectrum of $[\mathrm{PPN}]_{2}\left[\mathrm{Ti}_{2} \mathrm{Cl}_{10}\right]$ (maximum at $370 \mathrm{~cm}^{-1}$ ). The solid state spectrum of $[\mathrm{PPN}]_{2}\left[\mathrm{Ti}_{2} \mathrm{Cl}_{10}\right]$, shown in Figure 3(a), is characterized by a strong band around $365 \mathrm{~cm}^{-1}$, in-between those previously reported for the mono- and dinuclear ions, but quite close to the major 
band that is observed in solution. The overall shape of the two spectra, in dichloromethane solution and in the solid state, is very similar. We conclude that the compound structure is most certainly dinuclear both in solution and in the solid state. Thus, the rule stating that the pentachlorotitanate(IV) is mononuclear with large cations does not appear to have general validity, since $\mathrm{PPN}^{+}$is perhaps the largest cation with which this anion has ever been crystallized.

$<$ Figure 3>

The spectra of the $\left[\mathrm{Ti}_{2} \mathrm{Cl}_{9}\right]^{-}$and $\left[\mathrm{TiCl}_{6}\right]^{2-}$ salts, also shown in Figure 2, are quite different from that of the $\left[\mathrm{Ti}_{2} \mathrm{Cl}_{10}\right]^{2-}$ ion, demonstrating the suitability of IR spectroscopy in this spectral region for the analysis of the species present in solution. Complex $\left[\mathrm{Ti}_{2} \mathrm{Cl}_{9}\right]^{-}$has a very strong band centered at $428 \mathrm{~cm}^{-1}$ and a strong band at $390 \mathrm{~cm}^{-1}$. The shoulder on the right hand side of the latter band may be due to minor amounts of the $\left[\mathrm{Ti}_{2} \mathrm{Cl}_{10}\right]^{2-}$ salt. Complex $\left[\mathrm{TiCl}_{6}\right]^{2-}$, on the hand hand, is characterized by a strong and broad band centered at $327 \mathrm{~cm}^{-1}$. This corresponds to the frequency reported in the literature for the IR active stretching vibration $\left(v_{3}, T_{1 u}\right)$ of this ion (ca. $330 \mathrm{~cm}^{-1}$ depending on the counterion). ${ }^{[26,27,31]}$ It is worth to underline the weak band observed at $392 \mathrm{~cm}^{-1}$. Only two IR active bands (the $v_{3}$ stretching and the $v_{4}$ bending, both of $T_{1 u}$ type) are expected for the $O_{h}\left[\mathrm{TiCl}_{6}\right]^{2-}$ ion. According to the literature, these are located around $330 \mathrm{~cm}^{-1}$ and $183 \mathrm{~cm}^{-1}$, respectively. Therefore, the weak band at $392 \mathrm{~cm}^{-1}$ cannot belong to this ion. We believe that this band is due to oxo impurities deriving from a small amount of hydrolytic processes, given the extreme moisture sensitivity of the 
Ti(IV)-Cl bonds. In support of this hypothesis, we have observed that the relative intensity of this band changes as a function of the rigor with which the solutions are handled and increases when undried dichloromethane is used as solvent, but we have been unable to completely eliminate it. The reported spectrum was recorded in carefully dried solvent and all glassware and transfer syringes were silylated by rinsing with a $10 \%$ $\mathrm{v} / \mathrm{v}$ chloroform solution of $\mathrm{Me}_{3} \mathrm{SiCl}$. Possibly, some hydrolysis occurred during the isolation procedure (washings and transfer into the storage ampoules), as suggested by the observation of the same weak band in the IR spectrum of the solid sample, see Figure 3(c). Following this consideration, the band observed at ca. $390 \mathrm{~cm}^{-1}$ for the $\left[\mathrm{Ti}_{2} \mathrm{Cl}_{10}\right]^{2-}$ solution may also be due to a product of partial hydrolysis.

The spectrum of the $\left[\mathrm{TiCl}_{6}\right]^{2-}$ salt was also reproduced (except for the variable relative intensity of the $392 \mathrm{~cm}^{-1}$ band as outlined above) upon addition of $\geq 2$ equivalents PPNCl to the solution of $\left[\mathrm{Ti}_{2} \mathrm{Cl}_{10}\right]^{2-}$. The addition of just 1 equivalent of PPNCl to the same solution, on the other hand, shows the complete disappearance of the bands of $\left[\mathrm{Ti}_{2} \mathrm{Cl}_{10}\right]^{2-}$ and the appearance of a very strong band centered at $355 \mathrm{~cm}^{-1}$, see Figure 4 . It is to be noted that the band of $\left[\mathrm{TiCl}_{6}\right]^{2-}$ is also absent from this spectrum. This suggests the formation of a complex having the stoichiometry $\left[\mathrm{Ti}_{2} \mathrm{Cl}_{11}\right]^{3-}$. Addition of PPNCl to this solution generated again the spectrum of $\left[\mathrm{TiCl}_{6}\right]^{2-}$.

$<$ Figure 4>

Complex $\left[\mathrm{Ti}_{2} \mathrm{Cl}_{11}\right]^{3-}$ appears to be absent from the literature. Its structure most likely corresponds to a corner-sharing bioctahedron, see Equation 5. On the basis of 
VSEPR theory, the geometry around the bridging $\mathrm{Cl}$ atom should be bent and the IR spectrum can be predicted to be quite similar to that of mononuclear octahedral $\left[\mathrm{TiCl}_{6}\right]^{2-}$ if vibrational coupling across the $\mathrm{Cl}$ bridge is weak. Thus, the slight shift to higher frequency on going from $\left[\mathrm{TiCl}_{6}\right]^{2-}$ to $\left[\mathrm{Ti}_{2} \mathrm{Cl}_{11}\right]^{3-}\left(327\right.$ to $\left.355 \mathrm{~cm}^{-1}\right)$ signals a force constant increase upon reduction of the metal effective charge. Although the weak band at 392 $\mathrm{cm}^{-1}$ is identical to that observed for the $\left[\mathrm{TiCl}_{6}\right]^{2-}$ solution, therefore attributable to minor amounts of a hydrolytic product, its attribution to a genuine normal mode of the $\left[\mathrm{Ti}_{2} \mathrm{Cl}_{11}\right]^{3-}$ cannot be excluded. Once again, this spectrum was found to highly depend on the rigor with which the solution was prepared and the band at $392 \mathrm{~cm}^{-1}$ could never be completely eliminated. The reported spectrum was obtained from a solution prepared in silylated glassware and in carefully dried dichloromethane, from a solid sample that was obtained by direct synthesis in $\mathrm{SOCl}_{2}$, according to the stoichiometry of Equation 6 .

\section{Equation 5}

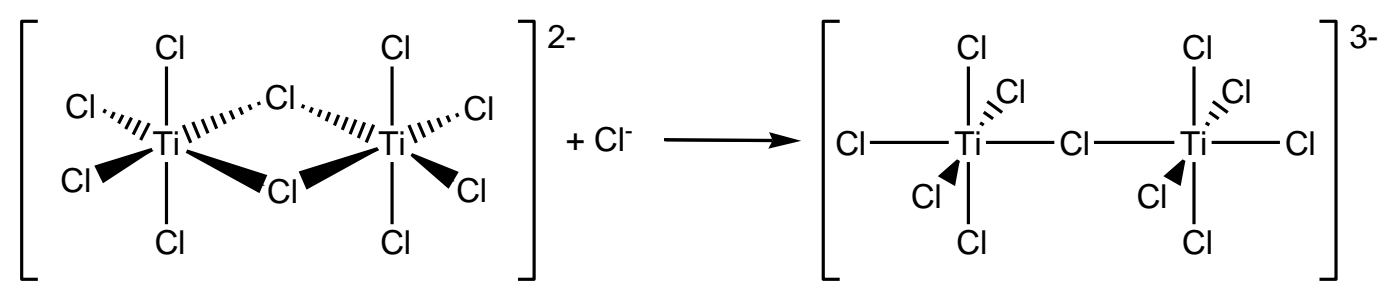

\section{Equation 6}

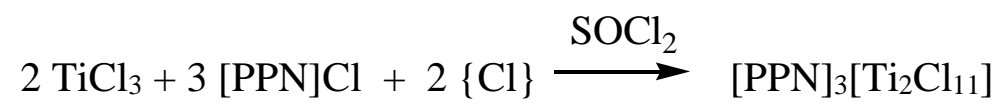


An additional interesting feature is shown by the IR spectrum of the $[\mathrm{PPN}]_{3}\left[\mathrm{Ti}_{2} \mathrm{Cl}_{11}\right]$ compound in the solid state, see Figure $3(\mathrm{~b})$. This is quite clearly the superposition of the spectra of the $[\mathrm{PPN}]_{2}\left[\mathrm{Ti}_{2} \mathrm{Cl}_{10}\right]$ and $[\mathrm{PPN}]_{2}\left[\mathrm{TiCl}_{6}\right]$ salts that are shown in the same figure, whereas the band observed for the same compound in solution is absent. This observation demonstrates that species $\left[\mathrm{Ti}_{2} \mathrm{Cl}_{11}\right]^{3-}$ exists only in solution, while the crystallization process forces a ligand redistribution to yield $\left[\mathrm{Ti}_{2} \mathrm{Cl}_{10}\right]^{2-}$ and $\left[\mathrm{TiCl}_{6}\right]^{2-}$. In other words, the ligand redistribution equilibrium shown in Equation 7 lies on the left in dichloromethane solution and on the right in the solid state for PPN salts.

\section{Equation 7}

$2\left[\mathrm{Ti}_{2} \mathrm{Cl}_{11}\right]^{3-} \rightleftarrows\left[\mathrm{Ti}_{2} \mathrm{Cl}_{10}\right]^{2-}+2\left[\mathrm{TiCl}_{6}\right]^{2-}$

As a final relevant observation, note that the solution spectrum of the $\left[\mathrm{Ti}_{2} \mathrm{Cl}_{10}\right]^{2-}$ salt (Figure 2) does not show a significant absorption at $355 \mathrm{~cm}^{-1}$, thus excluding the presence of large amounts of $\left[\mathrm{Ti}_{2} \mathrm{Cl}_{11}\right]^{3-}$ at equilibrium. A shoulder to the low frequency side of the $368 \mathrm{~cm}^{-1}$ band signals the possible presence of minor amounts of $\left[\mathrm{Ti}_{2} \mathrm{Cl}_{11}\right]^{3-}$, which could be related to an imprecise stoichiometry during the synthesis, or to a chloride redistribution equilibrium as shown in Equation 8. In the latter case, the equilibrium must necessarily be shifted almost completely towards the $\left[\mathrm{Ti}_{2} \mathrm{Cl}_{10}\right]^{2-}$ ion.

\section{Equation 8}

$2\left[\mathrm{Ti}_{2} \mathrm{Cl}_{10}\right]^{2-} \rightleftarrows\left[\mathrm{Ti}_{2} \mathrm{Cl}_{9}\right]^{-}+\left[\mathrm{Ti}_{2} \mathrm{Cl}_{11}\right]^{3-}$ 
In the light of the IR study, we can now re-interpret the result of the cyclic voltammetric experiment on the $\left[\mathrm{Ti}_{2} \mathrm{Cl}_{10}\right]^{2-}$ salt by assigning the wave at $-1.03 \mathrm{~V}$ to the reduction of the $\left[\mathrm{Ti}_{2} \mathrm{Cl}_{11}\right]^{3-}$ complex and the shoulder at ca. $-0.7 \mathrm{~V}$ to the reduction of $\left[\mathrm{Ti}_{2} \mathrm{Cl}_{9}\right]^{-}$. The cyclic voltammetric results would seem to indicate the presence of large amounts of the $\left[\mathrm{Ti}_{2} \mathrm{Cl}_{9}\right]^{-}+\left[\mathrm{Ti}_{2} \mathrm{Cl}_{11}\right]^{3-}$ species, i.e. the equilibrium of Equation 8 would seem shifted extensively toward the right hand side, in contrast with the IR results. There is in fact no contradiction between these two results because of the dynamic nature of the electrochemical experiment. Since the equilibration process described in Equation 8 may be quite fast and since the $\left[\mathrm{Ti}_{2} \mathrm{Cl}_{9}\right]^{-}$complex is reduced at a less negative potential, its consumption by the reduction process shifts the equilibrium to the right hand side at the expense of the $\left[\mathrm{Ti}_{2} \mathrm{Cl}_{10}\right]^{2-}$ ion in the electrode diffusion layer.

\section{(c) Structural characterization of $[\mathrm{PPN}]\left[\mathrm{Ti}_{2} \mathrm{Cl}_{9}\right]$}

Single crystals of the PPN salt of the $\left[\mathrm{Ti}_{2} \mathrm{Cl}_{9}\right]^{-}$species were grown from dichloromethane/pentane and were investigated by X-ray diffraction. The structure confirms the expected face-sharing bioctahedral geometry (see Figure 5). Bond lengths and angles within the anion are given in Table 2. The Ti-Cl bond lengths involving the bridging chlorine atoms are longer [2.4775(8) $\AA$ to $2.5098(8) \AA]$ than the terminal ones [2.1955(8) $\AA$ to $2.2216(8) \AA]$ as reported in related compounds containing the $\left[\mathrm{Ti}_{2} \mathrm{Cl}_{9}\right]^{-}$ anion. ${ }^{[1,32-36]}$ 


\section{Conclusions}

The two main novelties of this new study of the well developed coordination chemistry of chlorititanate(IV) complexes are: (i) the surprising oxidation of $\mathrm{TiCl}_{3}$ by thionyl chloride in the presence of chloride salts; (ii) the complex chloride dissociation and redistribution equilibria that are established by these anions, with the unambiguous identification in solution of the previously unknown, yet simple $\left[\mathrm{Ti}_{2} \mathrm{Cl}_{11}\right]^{3-}$ species. The

combined IR and electrochemical study has shown that: $(i)$ complex $\left[\mathrm{Ti}_{2} \mathrm{Cl}_{10}\right]^{2-}$ is dinuclear in dichloromethane solution and in the solid state as a $\mathrm{PPN}^{+}$salt; (ii) such ion is stable in dichloromethane but a chloride redistribution equilibrium to yield a mixture of $\left[\mathrm{Ti}_{2} \mathrm{Cl}_{9}\right]^{-}$and the novel $\left[\mathrm{Ti}_{2} \mathrm{Cl}_{11}\right]^{3-}$ complex is induced by the more facile electrochemical reduction of the former species; (iii) $[\mathrm{PPN}]_{3}\left[\mathrm{Ti}_{2} \mathrm{Cl}_{11}\right]$ is not a stable solid state species and redistributes to a mixture of $[\mathrm{PPN}]_{2}\left[\mathrm{Ti}_{2} \mathrm{Cl}_{10}\right]$ and $[\mathrm{PPN}]_{2}\left[\mathrm{TiCl}_{6}\right]$ upon crystallization.

Acknowledgement. We are grateful to the French Ministry of Research, to the Centre National de la Recherche Scientifique, and to Polimeri Europa for support of this work, and to Mr. Sébastien Maria for technical assistance.

\section{References}

[1] T. J. Kistenmacher, G. D. Stucky, Inorg. Chem 1971, 10, 122-132.

[2] C. Creaser, J. Creighton, J. Chem. Soc., Dalton Trans. 1975, 1402-1405.

[3] G. Natta, Angew. Chem. 1956, 68, 393.

[4] G. Natta, P. Corradini, G. Allegra, J. Polymer Sci. 1961, 51, 399.

[5] E. G. M. Tornqvist, J. T. Richardson, Z. W. Wilchinsky, R. W. Looney, J. Catal. 1967, 8, 189-196. 
[6] Z. W. Wilchinsky, R. W. Looney, E. G. M. Tornqvist, J. Catal. 1973, 28, 351367.

[7] H. Sinn, W. Kaminsky, Adv. Organomet. Chem. 1980, 18, 99-149.

[8] P. Pino, R. Mulhaupt, Angew. Chem., Int. Ed. Engl. 1980, 19, 857-875.

[9] C. G. Barraclough, A. K. Gregson, J. Chem. Soc., Faraday Trans. 2 1972, 68, 177-180.

[10] O. Kahn, Proc. Int. Conf. Coord. Chem., 16th 1974, 2.28a, 23 pp.

[11] A. Ceulemans, G. A. Heylen, L. F. Chibotaru, T. L. Maes, K. Pierloot, C. Ribbing, L. G. Vanquickenborne, Inorg. Chim. Acta 1996, 251, 15-27.

[12] P. C. Crouch, G. W. A. Fowles, R. A. Walton, J. Chem. Soc. (A) 1969, 972-976.

[13] B. Briat, O. Kahn, I. Morgensternbadarau, J. C. Rivoal, Inorg. Chem. 1981, 20, 4193-4200.

[14] D. Armstrong, P. Perkins, J. Stewart, Rev. Roum. Chim. 1974, 19, 1695-1707.

[15] H. Hecht, Z. anorg. Chem. 1947, 254, 37-51.

[16] A. Altomare, M. Burla, M. Camalli, G. Cascarano, C. Giacovazzo, A. Guagliardi, A. Moliterni, G. Polidori, R. Spagna, J. Appl. Cryst. 1999, 32, 115-119.

[17] G. M. Sheldrick, SHELXL97. Program for Crystal Structure refinement, University of Göttingen, Göttingen, Germany, 1997.

[18] L. J. Farrugia, J. Appl. Crystallogr. 1997, 32, 565.

[19] R. Colton, J. H. Canterford, Halides of the First Row Transition Metals, WileyInterscience, London, 1969.

[20] H. Heumann, P. Köchlin, Ber. 1883, 16, 1625.

[21] H. Stavdinger, W. Kreis, Helv. Chim. Acta 1924, 8, 71.

[22] H. Linga, Z. Stojek, R. A. Osteryoung, J. Am. Chem. Soc. 1981, 103, 3754-3760.

[23] R. T. Carlin, R. A. Osteryoung, J. S. Wilkes, J. Rovang, Inorg. Chem. 1990, 29, 3003-3009.

[24] N. Hao, B. Sayer, G. Denes, D. Bickley, C. Detellier, M. Mcglinchey, J. Magn. Reson. 1982, 50, 50-63.

[25] A. F. Demiray, W. Brockner, B. N. Cyvin, S. J. Cyvin, Z. Naturforsch. Sect. A 1979, 34A, 362-368.

[26] R. Clark, L. Maresca, R. Puddephat, Inorg. Chem. 1968, 7, 1603-\&.

[27] W. Van Bronswyk, R. Clark, L. Maresca, Inorg. Chem. 1969, 8, 1395-\&.

[28] O. Poleshchuk, J. Latosinska, B. Nogaj, J. Mol. Struct. 1996, 380, 277-282.

[29] C. Ding, Y. Yu, R. Jensen, W. Balfour, C. Qian, Chem. Phys. Lett. 2000, 331, 163-169.

[30] A. Shiga, H. Kawamurakuribayashi, T. Sasaki, J. Mol. Catal. 1994, 87, 243-261.

[31] D. M. Adams, J. Chatt, J. M. Davidson, J. Gerratt, J. Chem. Soc. 1963, 21892194.

[32] E. Solari, C. Floriani, A. Chiesi-Villa, C. Guastini, J. Chem. Soc., Chem. Commun. 1989, 1747-1749.

[33] E. Solari, C. Floriani, K. Schenk, A. Chiesi-Villa, C. Rizzoli, M. Rosi, A. Sgamellotti, Inorg. Chem. 1994, 33, 2018-2028.

[34] S. Castro, W. Streib, J. Huffman, G. Christou, Chem. Commun. 1996, 2177-2178.

[35] R. Bettenhausen, W. Milius, W. Schnick, Chem. Eur. J. 1997, 3, 1337-1341.

[36] Q. Feng, S. Luo, M. Olmstead, T. Rauchfuss, P. Stafford, Chem. Mater. 1997, 9, 641-643. 
Table 1. Crystal data and structure refinement for $[\mathrm{PPN}]\left[\mathrm{Ti}_{2} \mathrm{Cl}{ }_{9}\right]$.

Empirical formula

Formula weight

Temperature

Wavelength

Crystal system

Space group

Unit cell dimensions

Volume

Z

Density (calculated)

Absorption coefficient

$\mathrm{F}(000)$

Crystal size

Theta range for data collection

Index ranges

Reflections collected

Independent reflections

Completeness to theta $=26.37^{\circ}$

Absorption correction

Max. and min. transmission

Refinement method

Data / restraints / parameters

Goodness-of-fit on $\mathrm{F}^{2}$

Final R indices [I>2sigma(I)]

$\mathrm{R}$ indices (all data)

Largest diff. peak and hole
$\mathrm{C}_{36} \mathrm{H}_{30} \mathrm{Cl}_{9} \mathrm{~N} \mathrm{P}_{2} \mathrm{Ti}_{2}$

953.40

293(2) K

$0.71073 \AA$

Triclinic

$\mathrm{P}-1$

$\mathrm{a}=9.9904(10) \AA \quad \alpha=86.057(8)^{\circ}$.

$\mathrm{b}=12.0458(12) \AA \quad \beta=82.379(8)^{\circ}$.

$\mathrm{c}=17.4335(14) \AA \quad \gamma=83.861(8)^{\circ}$.

2064.4(3) $\AA^{3}$

2

$1.534 \mathrm{Mg} / \mathrm{m}^{3}$

$1.075 \mathrm{~mm}^{-1}$

960

$0.16 \times 0.09 \times 0.04 \mathrm{~mm}^{3}$

2.95 to $26.37^{\circ}$.

$-12<=\mathrm{h}<=9,-15<=\mathrm{k}<=15,-21<=\mathrm{l}<=21$

16046

8414 [R(int) $=0.0421]$

$99.7 \%$

Analytical

0.92334 and 0.78155

Full-matrix least-squares on $\mathrm{F}^{2}$

8414 / 0 / 451

0.795

$\mathrm{R} 1=0.0348, \mathrm{wR} 2=0.0496$

$\mathrm{R} 1=0.0706, \mathrm{wR} 2=0.0554$

0.349 and -0.428 e. $\AA^{-3}$ 
Table 2. Bond lengths $[\AA]$ and angles $\left[^{\circ}\right]$ for $[\mathrm{PPN}]\left[\mathrm{Ti}_{2} \mathrm{Cl}_{9}\right]$.

\begin{tabular}{|c|c|c|c|c|}
\hline $\mathrm{Ti}(1)-\mathrm{Ti}(2)$ & \multicolumn{2}{|c|}{$3.3922(7)$} & & \\
\hline $\mathrm{Ti}(1)-\mathrm{Cl}(11)$ & \multicolumn{2}{|c|}{$2.2216(8)$} & $\mathrm{Ti}(2)-\mathrm{Cl}(21)$ & $2.2124(9)$ \\
\hline $\mathrm{Ti}(1)-\mathrm{Cl}(12)$ & \multicolumn{2}{|c|}{$2.1955(8)$} & $\mathrm{Ti}(2)-\mathrm{Cl}(22)$ & $2.2175(9)$ \\
\hline $\mathrm{Ti}(1)-\mathrm{Cl}(13)$ & \multicolumn{2}{|c|}{$2.2046(9)$} & $\mathrm{Ti}(2)-\mathrm{Cl}(23)$ & $2.2031(9)$ \\
\hline $\mathrm{Ti}(1)-\mathrm{Cl}(31)$ & \multicolumn{2}{|c|}{$2.4620(8)$} & $\operatorname{Ti}(2)-\mathrm{Cl}(31)$ & $2.4937(8)$ \\
\hline $\mathrm{Ti}(1)-\mathrm{Cl}(32)$ & \multicolumn{2}{|c|}{$2.5098(8)$} & $\mathrm{Ti}(2)-\mathrm{Cl}(32)$ & $2.4785(8)$ \\
\hline $\mathrm{Ti}(1)-\mathrm{Cl}(33)$ & \multicolumn{2}{|c|}{$2.4775(8)$} & $\mathrm{Ti}(2)-\mathrm{Cl}(33)$ & $2.4496(8)$ \\
\hline \multicolumn{2}{|c|}{$\mathrm{Cl}(12)-\mathrm{Ti}(1)-\mathrm{Cl}(11)$} & $98.02(3)$ & $\mathrm{Cl}(21)-\mathrm{Ti}(2)-\mathrm{Cl}(22)$ & $97.49(4)$ \\
\hline \multicolumn{2}{|c|}{$\mathrm{Cl}(13)-\mathrm{Ti}(1)-\mathrm{Cl}(11)$} & $97.12(3)$ & $\mathrm{Cl}(23)-\mathrm{Ti}(2)-\mathrm{Cl}(21)$ & $96.84(3)$ \\
\hline \multicolumn{2}{|c|}{$\mathrm{Cl}(12)-\mathrm{Ti}(1)-\mathrm{Cl}(13)$} & $99.71(3)$ & $\mathrm{Cl}(23)-\mathrm{Ti}(2)-\mathrm{Cl}(22)$ & $98.94(4)$ \\
\hline \multicolumn{2}{|c|}{$\mathrm{Cl}(11)-\mathrm{Ti}(1)-\mathrm{Cl}(31)$} & $91.45(3)$ & $\mathrm{Cl}(21)-\mathrm{Ti}(2)-\mathrm{Cl}(31)$ & $91.30(3)$ \\
\hline \multicolumn{2}{|c|}{$\mathrm{Cl}(11)-\mathrm{Ti}(1)-\mathrm{Cl}(32)$} & $90.86(3)$ & $\mathrm{Cl}(21)-\mathrm{Ti}(2)-\mathrm{Cl}(32)$ & $89.43(3)$ \\
\hline \multicolumn{2}{|c|}{$\mathrm{Cl}(11)-\mathrm{Ti}(1)-\mathrm{Cl}(33)$} & $166.67(3)$ & $\mathrm{Cl}(21)-\mathrm{Ti}(2)-\mathrm{Cl}(33)$ & $166.33(3)$ \\
\hline \multicolumn{2}{|c|}{$\mathrm{Cl}(12)-\mathrm{Ti}(1)-\mathrm{Cl}(31)$} & $91.01(3)$ & $\mathrm{Cl}(22)-\mathrm{Ti}(2)-\mathrm{Cl}(31)$ & $89.23(3)$ \\
\hline \multicolumn{2}{|c|}{$\mathrm{Cl}(12)-\mathrm{Ti}(1)-\mathrm{Cl}(32)$} & $165.52(3)$ & $\mathrm{Cl}(22)-\mathrm{Ti}(2)-\mathrm{Cl}(32)$ & $165.02(3)$ \\
\hline \multicolumn{2}{|c|}{$\mathrm{Cl}(12)-\mathrm{Ti}(1)-\mathrm{Cl}(33)$} & $91.65(3)$ & $\mathrm{Cl}(22)-\mathrm{Ti}(2)-\mathrm{Cl}(33)$ & $92.14(3)$ \\
\hline \multicolumn{2}{|c|}{$\mathrm{Cl}(13)-\mathrm{Ti}(1)-\mathrm{Cl}(31)$} & $165.17(3)$ & $\mathrm{Cl}(23)-\mathrm{Ti}(2)-\mathrm{Cl}(31)$ & $167.58(3)$ \\
\hline \multicolumn{2}{|c|}{$\mathrm{Cl}(13)-\mathrm{Ti}(1)-\mathrm{Cl}(32)$} & $90.45(3)$ & $\mathrm{Cl}(23)-\mathrm{Ti}(2)-\mathrm{Cl}(32)$ & $93.37(3)$ \\
\hline \multicolumn{2}{|c|}{$\mathrm{Cl}(13)-\mathrm{Ti}(1)-\mathrm{Cl}(33)$} & $90.21(3)$ & $\mathrm{Cl}(23)-\mathrm{Ti}(2)-\mathrm{Cl}(33)$ & $91.19(3)$ \\
\hline \multicolumn{2}{|c|}{$\mathrm{Cl}(31)-\mathrm{Ti}(1)-\mathrm{Cl}(32)$} & $77.29(3)$ & $\mathrm{Cl}(32)-\mathrm{Ti}(2)-\mathrm{Cl}(31)$ & $77.29(3)$ \\
\hline \multicolumn{2}{|c|}{$\mathrm{Cl}(31)-\mathrm{Ti}(1)-\mathrm{Cl}(33)$} & $79.18(3)$ & $\mathrm{Cl}(33)-\mathrm{Ti}(2)-\mathrm{Cl}(31)$ & $79.11(3)$ \\
\hline \multicolumn{2}{|c|}{$\mathrm{Cl}(33)-\mathrm{Ti}(1)-\mathrm{Cl}(32)$} & $77.92(3)$ & $\mathrm{Cl}(33)-\mathrm{Ti}(2)-\mathrm{Cl}(32)$ & $79.04(3)$ \\
\hline
\end{tabular}




\section{Captions for Figures}

Figure 1. Cyclic voltammograms of solutions of $\left[\mathrm{NBzEt}_{3}\right]_{2}\left[\mathrm{Ti}_{2} \mathrm{Cl}_{10}\right]$ alone (thicker line) and with two equiv of $\left[\mathrm{NBzEt}_{3}\right] \mathrm{Cl}$ (thinner line). Both solutions also contain the internal ferrocene standard (reversible wave at $\mathrm{E}_{1 / 2}=0$ ). Solvent: $\mathrm{CH}_{2} \mathrm{Cl}_{2}$.

Figure 2. Infrared spectra of various chlorotitanate(IV) $\mathrm{PPN}$ salts in $\mathrm{CH}_{2} \mathrm{Cl}_{2}$ solution $\left(\right.$ Ti concentration $\left.=2 \times 10^{-2} \mathrm{M}\right)$. The starred peak corresponds to an oxo impurity, see text.

Figure 3. Solid state (Nujol mull) infrared spectra of (a) $[\mathrm{PPN}]_{2}\left[\mathrm{Ti}_{2} \mathrm{Cl}_{10}\right]$, (b) $[\mathrm{PPN}]_{3}\left[\mathrm{Ti}_{2} \mathrm{Cl}_{11}\right],(\mathrm{c})[\mathrm{PPN}]_{2}\left[\mathrm{TiCl}_{6}\right]$

Figure 4. Infrared spectrum of a $\mathrm{CH}_{2} \mathrm{Cl}_{2}$ solution of $[\mathrm{PPN}]_{3}\left[\mathrm{Ti}_{2} \mathrm{Cl}_{11}\right]$ (Ti concentration $\left.=2 \times 10^{-2} \mathrm{M}\right)$.

Figure 5. An ORTEP view of the anion of compound $[\mathrm{PPN}]_{2}\left[\mathrm{Ti}_{2} \mathrm{Cl}_{9}\right]$. Ellipsoids are drawn at the $50 \%$ probability level. 
Figure 1

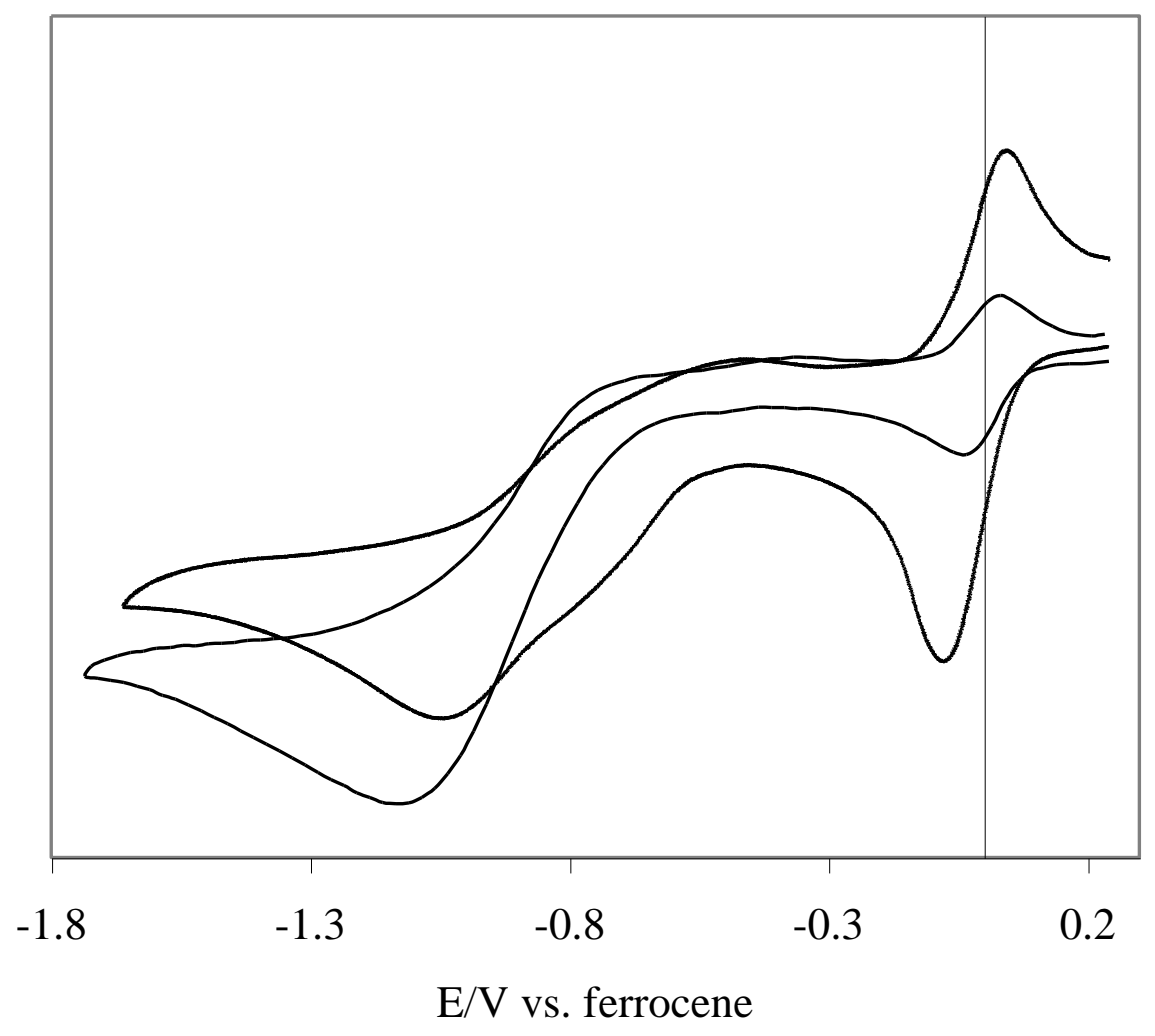


Figure 2

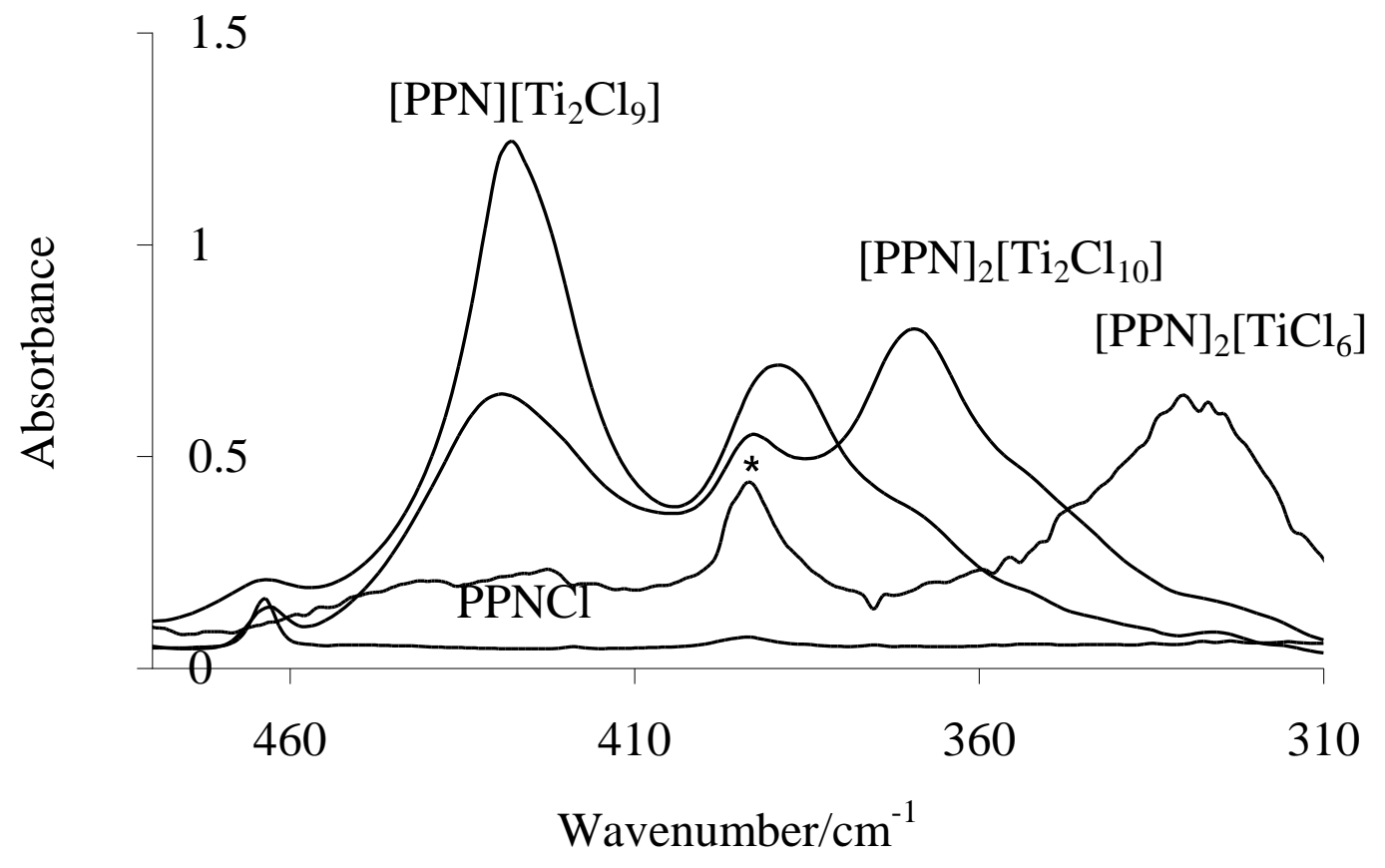


Figure 3

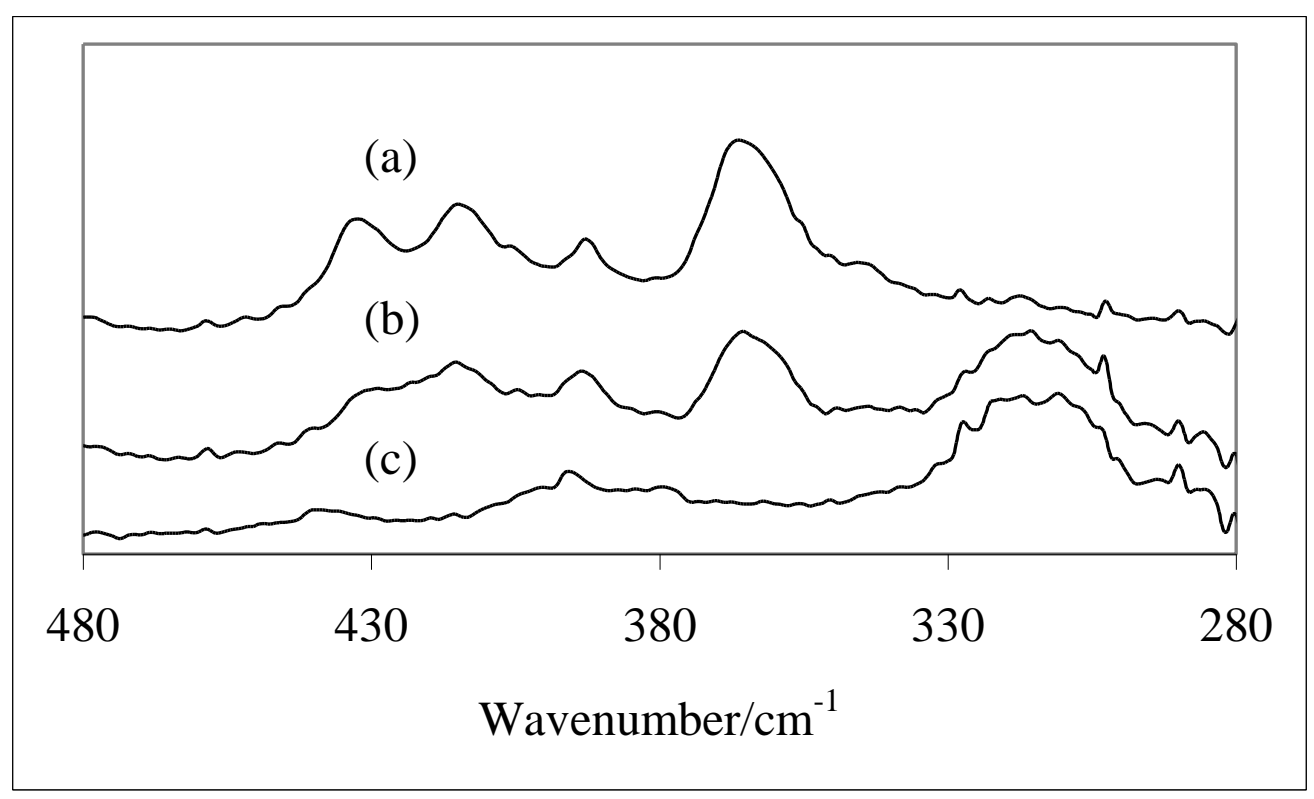


Figure 4

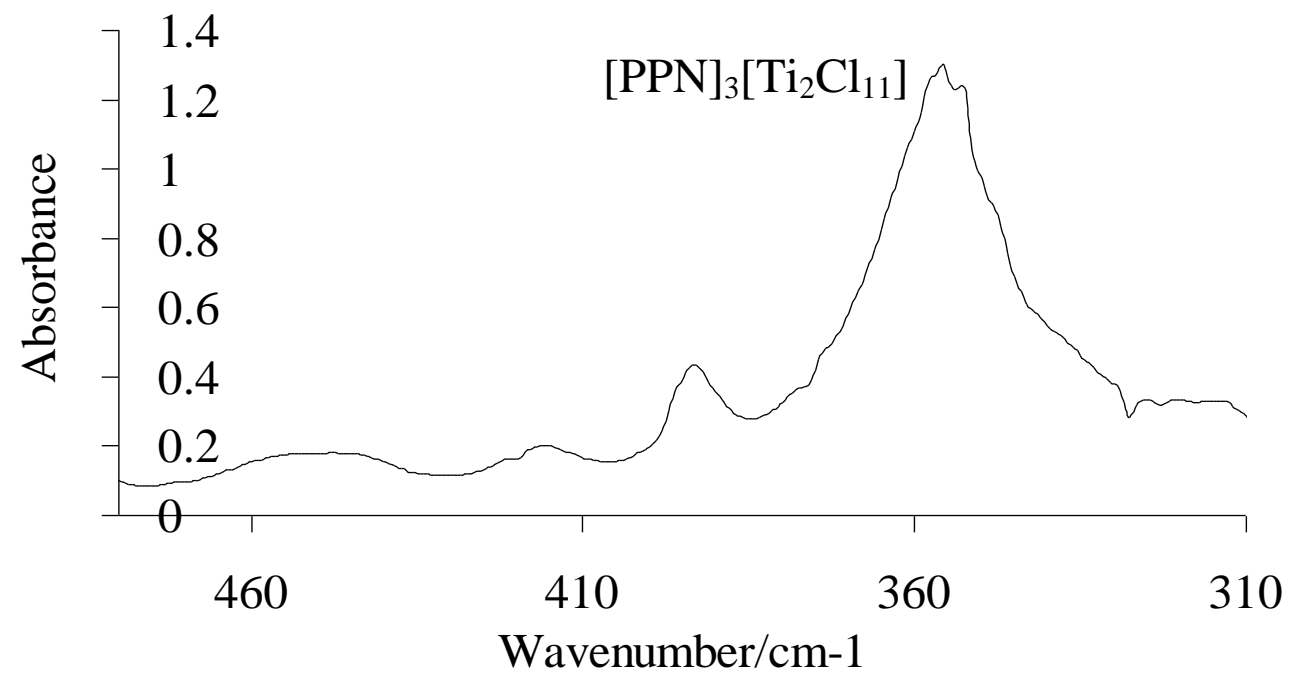


Figure 5

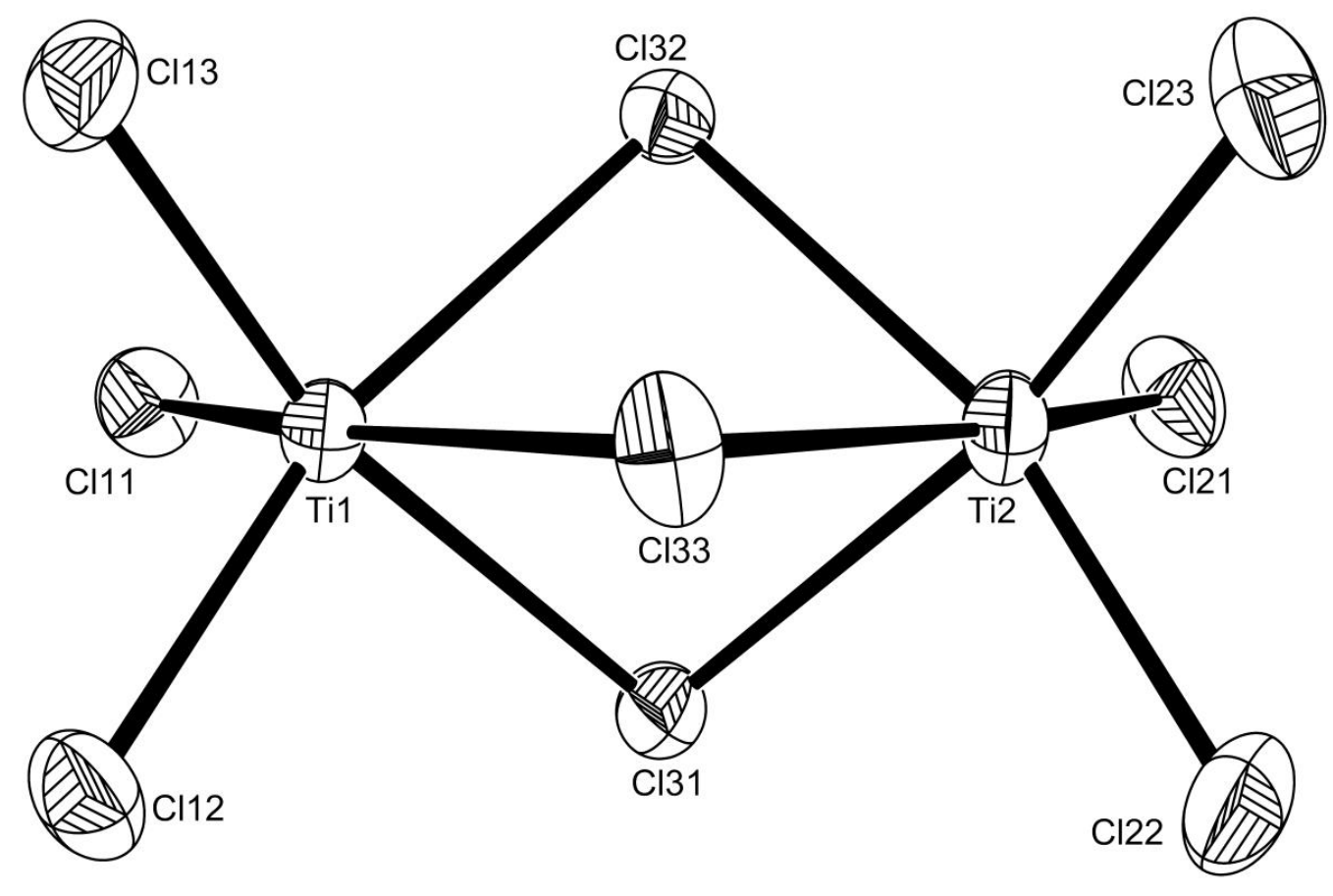

